\title{
ONLINE LEARNING DURING COVID-19 PANDEMIC: PROBLEMS FACED BY MIDWIFERY STUDENTS OF STIK BINA HUSADA PALEMBANG AND SUGGESTIONS TO ENHANCE EFFECTIVENESS
}

\author{
By: \\ Agus Wahyudi \\ Nursing Science Study Program, STIK Bina Husada Palembang, South Sumatera \\ wahyudiagus.aw@gmail.com
}

\begin{abstract}
COVID-19 or widely known as Corona Virus Disease 2019 influences the teaching and learning process in the world. Due to prevent the spread of the virus, the Ministry of Education and Culture asks the teachers to teach the students using online learning. Therefore, this study aimed to find out the problems faced by the midwifery students of STIK Bina Husada Palembang and suggestions to enhance the effectiveness of online learning. Descriptive research was applied. There were 35 students involved in this research, namely Midwifery students of STIK Bina Husada Palembang in the academic year of 2020/2021. The data were collected using a questionnaire and were analyzed qualitatively with an interactive model, covering data collection, data reduction, presentation, and conclusion. Having implemented online learning during the Covid-19 Pandemic, the students, parents, and teachers got problems with online learning. The problems can be overcome by implementing some suggestions mentioned in this research.
\end{abstract}

Keywords: online learning, problems, suggestions, effectiveness

\section{INTRODUCTION}

One more year has passed, stay at home and work from home, and elearning for students are following the government program to break the chain of Covid-19 pandemic (coronavirus disease) which is very deadly to people when they have the virus. This virus is considered as a warning to mankind so that all care of

God's creation again.

The Covid-19 gives a bad effect on our life. As reported by JHU CSSE Covid 19 Data (2020), in the last 14 days from 25 March 2020, there were 1.47 million cases, of which 1.3 million cases recovered and 39.685 were reported dead in Indonesia. 
The business world also faces very tough challenges. About half of the world's 3.3 billion workers face the risk of lack of money and/or losing their jobs to various degrees. The informal economy has also been hit hard. Millions of farmers in the world, as well as migrant workers, face a tough economic situation with reduced or even loss of their income.

Furthermore, the Covid-19 pandemic gives an effect on students' mental or psychological. Besides, the need for academic adjustment and social restrictions can generate negative feelings. As supported by KPAI Commissioner for Education Listyarti (2020) at a KPAI event in Jakarta, Monday (29/6/2020) who mentions that many students were stressed out that they dropped out of school while participating in online learning.
There are many impacts on the sustainability of education caused by the Covid-19 pandemic. Aji, (2020) states that there are two impacts on educational systems. First, it is a short-term impact. This impact is felt by many households in Indonesia. Many families are less familiar do homeschooling in our country. They tend to choose a formal school for their children. It can be stated that most parents are doubtful to select homeschooling and to be 'teachers' for their children. It is common sense to see that many parents think that homeschooling is moving schools to homes. Consequently, the parents are considered to be the teachers for their children. Besides, many citizens in Indonesia will be disclosed to the long-term impact of Covid-19. The second is the long-term impact where 
there will be an increase in inequality among groups' communities or regions in Indonesia. Aditama (2020) also adds that the socio-economic disruption caused by Covid-19 was very large. This fact is based on WHO and the International Labor Organization Food and Agriculture Organization, and the International Fund for Agricultural Development in October 2020. It can be assumed that tens of millions of people could fall into extreme poverty. Due to poverty, some malnourished people in the world will be increased.

Concerning the impact of the Covid-19, Abidah, Hidaayatullaah, Simamora, Fehabutar, and Mutakinati (2020) mention that the Covid-19 has an important effect on the educational system in Indonesia. Commonly, teachers and students interact in the classroom. Due to the Covid- pandemic, the teaching and learning process changes into distance learning.

Since the Covid-19 gives bad effects on education, the Ministry of Education and Culture has facilitated the way of students' learning at home by providing distance learning applications based on portal and android "Rumah Belajar with some excellent features that can be accessed by students and teachers. Besides, seven online learning platforms such as Smart Class, Ruang guru, Sekolahmu, Zenius, Quipper, Google Indonesia, and Microsoft support education in the schools. Each platform can be accessed freely (Kemdikbud, 2020a). Using the facilitation given by the Ministry of Education and Culture, hopefully, students can learn every day at home without going to school. 
However, the implementation of the distance learning system in Indonesia makes our country must work hard to change the system of education quickly. Besides, the online learning system forces teachers, students, and parents to be techsavvy. As a result, the acceleration of the transformation of educational technology increases and supports the advancement of the Industrial Revolution 4.0.

Siemens, Gašević, and Dawson (2015) explain that online learning, one of distance education, uses technology to support the learning process by using the internet to do the process of teaching. Further, the Higher Education Law number 12 of 2012, section 31 concerning Distance Education describes that distance learning is the way for a teacher to transfer knowledge to the students using various communication media. By doing distance learning, the students should not attend the class and study face to face and enlarge the accessibility and facilitation of higher education services in education and learning. It is also done using various forms, modes, and coverage provided by learning facilities and services and an assessment system that guarantees the quality of graduates following the National Higher Education Standards. Dabbagh (2007) also explains that the successful online learner can be seen based on the characters and abilities, such as have a solid scholarly self-concept, show the capability of using online learning technologies, hold interpersonal and communication skills, comprehend and praise interaction and collaborative learning, own an inner locus of control, show self-directed 
learning skills, and exhibit a required affiliation.

However, we need to know that online learning will not be possible if schools and parents do not have sufficient capital to access the tools. Online learning will not be carried out if students do not have adequate computers, cell phones, internet quotas, and internet networks. In the process, there are many obstacles during the online learning process. The obstacles faced are students' saturation in carrying out learning that is more monotonous because the teacher assigns many tasks to students. The constraints of the availability of adequate electronic devices, quotas, and networks are also a matter of concern for students. Using these constraints, students will experience learning difficulties in implementing online learning.
Moreover, the changes system from offline learning to an online system happened immediately because the Covid-19 pandemic did not start with careful preparation. It can be seen from the teachers who have less knowledge of ICT skills so that they cannot adjust to transforms technology and information-based learning. It cannot be denied that teachers must apply technology in teaching. During the Covid-19 pandemic, teachers must carry out ICT-based learning, therefore, the learning process runs continuously. Nevertheless, teachers' roles cannot be displaced by technology. The utilization of technology in education is only to simplify teachers to transfer knowledge and not to establish students' character.

Moreover, Kemdikbud (2020b) explains that learning from home is 
applied to support students with meaningful experiences without completing all materials. Besides, learning at home can encourage students to learn life skills education including on the COVID-19 pandemic. The activities and tasks can be done variously between students based on their interests and conditions and depends on the gap of access/learning facilities at home.

From the depiction above, it is reasonable that online learning can be used as an alternative way to do the learning process for students due to the Covid-19 widespread condition. Although the implementation of online learning can be difficult, teachers, students, and parents should have well prepared. As a result, the writer wanted to investigate the obstacles that appeared by the student in the utilization of online learning and to find the solution so that the teaching process can run effectively.

\section{METHODOLOGY}

The researcher used a descriptive study in conducting the present research. Descriptive research focuses on the way of gathering the data, analyze, and interpret the meaning of the data. The population of this study was students of the Midwifery study program of STIK Bina Husada Palembang, which was the fourth semester in the academic year of 2020/2021 with 35 students. To gather the data, a questionnaire was applied to seek the students' problems during online learning.

\section{RESULT AND DISCUSSION \\ The results of this research are explained as follows.}


- Students' Problem during 50.000,- until Rp. 100.000,- and Online Learning during $11.4 \%$ of the students stated more

\section{Covid-19 Pandemic}

The results of the questionnaire indicated that there were many online learning applications used during the Covid-19 Pandemic, such as zoom meetings, google meetings, WhatsApp, and Edlink. The first questionnaire asked about the most applications used as online learning media. Most students (91\%) answered that Google meeting and zoom meeting and the rest of the students (9\%) answered WhatsApp and Edlink.

The second question was the students' budget for the internet quota. $54.3 \%$ of the students answered the internet quota they spent a month started from Rp. 100.000,- until Rp. 200.000,-, 34.3\% of the students answered from $\mathrm{Rp}$. than Rp. 200.000,-

The third question was the level of the difficulties in running the online learning application, $71.4 \%$ of the students stated the application used was quite easy, $11.4 \%$ of the students stated easy, and $17.2 \%$ of the students stated difficult.

The fourth question of the questionnaire is related to the level of interest in the teaching and learning process through online learning applications, the majority of the students or $54.3 \%$ were less interested, $8.6 \%$ of the students were not interested at all, $34.3 \%$ of the students were interested, and $2.8 \%$ of the students were very interested.

The fifth question was about carrying out the instructional process during the Covid-19 pandemic, $48.6 \%$ 
of students answered they were carried out well, $37.1 \%$ of the students stated adequate, $11.4 \%$ of the students stated very well and $2.9 \%$ of the students were not.

The sixth question asked whether online learning that has been done master the learning objectives, (tutorials, lectures, practicum, CSL) or not. $57.1 \%$ of the students stated that the online learning applications adequate to master the learning objective, $22.9 \%$ of the students stated master, $17.1 \%$ of the students stated master, and $2.9 \%$ of the students stated not master the learning objective.

The last question was about the internet signals when participating in online learning activities. Most students $(94.3 \%)$ said that they had a problem with the internet signal and $5.7 \%$ of the students said no.
- The Suggestions to Online Learning Problem during the

\section{Covid-19 Pandemic}

To lessen the barrier of online learning faced by the students of the Midwifery study program of STIK Bina Husada Palembang, several solutions can be applied Internet quota is hand in hand with the ICT equipment possessed by the students; if they do not have a mobile phone or notebook to study using online learning applications, they can use their family's devices. If they do not have internet network access, they can write their tasks manually. As a result, students must study and stay at home. Next, students who have bad internet connection problems can be helped by asking them to join their family members, or by saving data usage. Moreover, they can download the 
learning materials from YouTube and watch them offline to save the internet quota.

There are many things that Online learning during the Covid-19 pandemic should notice to many things, for example, the instructional goal should be achieved and it should not overload the students with burdensome tasks. Further, it should provide a meaningful learning experience for the students, and the teaching material provided by the teacher should focus on life skill education.

\section{CONCLUSION}

The execution of online learning or E-learning due to the Covid 19 pandemic has many problems and obstacles. They are experienced by students, teachers, and also parents. The students' problems included quota restrictions, even though the government already provides internet quotas, a lack of learning equipment or services, a desire to learn, and the ability to run the application. Those different issues can be overwhelmed by executing a few of the methodologies referenced in this research. Those systems were revealed by previous experts, and the analyst added a few procedures.

\section{REFERENCES}

Abidah, A., Hidaayatullaah, H.N Simamora, R., M., Fehabutar, D., \& Mutakinati, L. (2020). The impact of Covid-19 to Indonesian education and its relation to the philosophy of "Merdeka Belajar." Studies in Philosophy of Science and Education (SiPoSE), 1, 38-49. Retrieved from https://media.neliti.com/media/p ublications/316626-the-impactof-covid-19-to-indonesian-edudf1bb916.pdf

Aditama, T, y. (2020). Dampak ekonomi pandemi Covid-19. Retrieved April 14 ${ }^{\text {th }}$, 2021 from https://analisis.kontan.co.id/news /dampak-ekonomi-pandemicovid-19 
Aji, R. H. S. (2020). Dampak Covid19 pada Pendidikan di Indonesia: Sekolah, Keterampilan, dan Proses Pembelajaran. SALAM: Jurnal Sosial Dan Budaya SyarI, 7(5), 395-402. https://doi.org/10.15408/sjsbs.v7 i5.15314

Dabbagh, N. (2007). The online learner: Characteristics and pedagogical implications. Contemporary Issues in Technology and Teacher Education, 7(3), 217-226.

JHU CSSE Covid 19 Data. (2020). Novel Coronavirus (COVID-19) Cases. Retrieved March $26^{\text {th }}$, 2020 from https://github.com/CSSEGISand Data/COVID-19

Kemdikbud. (2020a). Cegah sebaran Covid19 di satuan pendidikan, Kemendikbud gandeng swasta siapkan solusi belajar daring. Retrieved January 22 $2^{\text {nd }}, 2021$ from https://www.kemdikbud.go.id/m ain/blog/2020/03/cegah-sebarancovid19-disatuan-pendidikankemendikbud-gandeng-swastasiapkan-solusi-belajar-darin

Kemdikbud. (2020b). Education minister issues circular on policy education amidst Covid-19 outbreak. Retrieved December $23^{\text {rd }}, \quad 2020$ from https://setkab.go.id/en/educationminister-issues-circular-onpolicy-education-amidst-covid19-outbreak/
Listyarti, R. (2020). KPAI: Banyak siswa stress hingga putus sekolah selama ikuti PKK Darin. Retrieved April 14 ${ }^{\text {th }}, 2021$ from https://www.antaranews.com/ber ita/1628246/kpai-banyak-siswastres-hingga-putus-sekolahselama-ikuti-pjj-daring $\% 0 \mathrm{~A} \% 0 \mathrm{~A}$

Siemens, G., Gašević, D., \& Dawson, S. (2015). Preparing for the digital university: A review of the history and current state of distance, blended, and online learning. Retrieved March $2^{\text {nd }}$, 2021

from http://linkresearchlab.org/prepari ngdigitaluniversity.pdf\%0A\%0A 